the tubes out significantly reduces the transfer problem, helped only by using nonabsorptive material such as polyethylene, polyolein, or polyurethane. Polyvinyl chloride is worse than rubber in this respect. ${ }^{3}$

While Ellis et al. may have taken the necessary precautions, unfortunately we cannot know this unless they are reported. Since we do not know the triggering dosage of halothane or any other substance in humans we must assume that these quantities are significant until proved otherwise.-I am, etc.,

J. A. LACK

Anaesthetic Department,

Salisbury General Hospital

Salisbury, Wilts

1 Ellis, F. R., et al., British Medical fournal, 1974, $4,270$.
Titel. J.

2 Titel. J. H., and Lowe, H. J., Anaesthesiology, $1968,29,1215$.

Lowe, H. J. Dose-regulated Penthrane Anaes-
thesia, p. 9 Q Queenborough, Abbott Laboratories, 1972.

\section{Geriatric Policies}

SIR,-The recent tragedy in a Nottingham old people's home raises not only the issue of safety in these homes but also that of the suitability of some of these old people to be admitted to these homes.

In most areas of this country there are active old people occupying hospital beds, while some of the residents of old people's homes are bedfast. This can lead on occasion to acrimony between the hospital service (usually, but by no means exclusively, the department of geriatric medicine) and the social services, neither of which is able to fulfil its obligations to the community because of its limited resources.

There is a tendency for social services departments when assessing clients for part 3 accommodation to say to themselves, "This individual cannot manage in this environment, we must change the environment" without considering sufficiently, since they do not have the training, to what extent the individual can be changed-that is, habilitated so that he can remain in his home environment.

In the main the primary health care physician and his team do not have the facilities or expertise adequately to carry out this function. I would therefore suggest that assessment of suitability for part 3 accommodation should be a joint undertaking between social services and departments of geriatric medicine so that correct placement and maximum habilitation can be achieved. -I am, etc.,

Geriatric Research Unit, St. John's Hospital,

SIR,-While I take issue with Professor G. F. Adams over his paper "Eld Health" (28 September, p. 789), I do not feel as strongly as Dr. H. M. Hodkinson that he is guilty of denigrating his colleagues (2 November, p. 290). If those of us who claim the advantages of high turnover and low waiting list wish to be taken seriously we must take care to show beyond reasonable doubt, firstly, that the advantages we claim for our approach are shared by the community. Secondly, we must show that we can contain the difficult geriatric case load from our district and have taken account of any help received from other hospital departments, neighbouring geriatric departments, the social services department, and institutions run by sympathetic religious bodies. It is important to appreciate that this help may be given to the geriatric department directly by transfer to these institutions or indirectly by admission from the community to these institutions. Hospital activity analysis is probably the best method of demonstrating the extent and significance of such invisible exports. Finally, we must show that our approach has worked for a minimum of 10 years. I would suggest that the paper by O'Brien et al. ${ }^{1}$ satisfies these criteria.

Old people, particularly if they are sick, are in danger of institutionalization in the community just as they are in hospital or old people's homes. Such people generally come for the first time to the notice of the local authority or hospital services when the community finally rejects them. The difficulty of their subsequent rehabilitation and return to the community is far greater if seen at this stage of their illness than if seen earlier, before their rejection and before their institutionalization. Destruction of this vicious circle is surely the nub of geriatric medicine. A hospital geriatric service, if it is to be adequate, must take on the task of cultivating the community. This cannot be achieved without high turnover or low waiting list.

Sir Heneage Ogilvie ${ }^{2}$ also said, "We must seek truth, remembering that when we meet her it may be in a guise we do not expect and coming from a quarter we have despised, and when we have found her we must follow her."-I am, etc.,

Manor Park Hospital,
Bristol

W. H. LLOYD

1 O'Brien, T. D., Joshi, D. M., and Warren, E. W., British Medical fournal, 1973, 4, 277.
Ogilvie, H., British Medical fournal, 1949, 2, 663.

\section{Oral Contraceptives and the Liver}

SIR,--In your leading article on this subject (23 November, p. 430) no mention was made of porphyria cutanea tarda symptomatica (P.C.T.S.). T'is form of porphyria is now well recognized as a rare complication of oral contraceptive medication ${ }^{1}$ and as a reliable cutaneous marker of liver cell damage.

In the past four years we have encountered five patients, aged 20-31, who have developed P.C.T.S. while taking oral contraceptives and in three of these the aspartate aminotransferase level was moderately raised, though other conventional tests of liver function were normal. In none of the patients was there any history of previous liver disease, porphyria in other members of the family, or more than infrequent social drinking. In three of our patients the porphyria appeared within six months of starting oral contraceptives. In some patients it may disappear when oral contraceptives are stopped, but in others treatment by repeated venesection is necessary. Persistence of the porphyria during subsequent pregnancy has been reported. ${ }^{2}$ Though there have been a few reports of P.C.T.S. occurring in more than one member of a family, we are not aware that a familial basis of this reaction to oral contraceptives has been demonstrated.

It is probable that the oestrogenic component precipitates P.C.T.S. in these patients since the syndrome also occurs in patients treated with natural and synthetic oestrogens for carcinoma of the prostate or menopausal symptoms. ${ }^{3}$ Though the mechanism of this action of oestrogen in, presumably, susceptible patients is not understood, it is clear that it is a reaction distinct from the precipitation of acute attacks of porphyria by oestrogens or progestogens in patients with acute intermittent ${ }^{4}$ or variegate porphria. ${ }^{5}$ Rarely, oral contraceptives may exacerbate the cutaneous manifestations of variegate porphyria, but this effect appears to be secondary to their cholestatic action and is associated with jaundice and diversion of porphyrins from the biliary route of excretion. ${ }^{6}$

It is important to ensure that P.C.T.S. and variegate porphyria are not confused when a young woman presents with the characteristic skin lesions of the cutaneous hepatic porphyrias. This can be achieved only by appropriate laboratory investigation of samples of urine and faeces from the patient and, if necessary, other members of her family. ${ }^{7}$ - We are, etc., -

G. H. ELDER

Department of Medical Biochemistry,

Welsh National School of Medicine, Cardiff

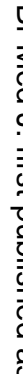

Department of Photobiology,

I. A. MAGNuS Institute of Dermatology, London E.9

1 Baker, H., British fournal of Dermatology, 1969,

81 946,.
Borrie, P. F., Case 41, British Association of Dermatology, 52nd Annual Summer Meeting, July 1972 .

3 Roenigk, H. H., and Gottlob, M. E., Archives of Dermatology, 1970, 102, 260

Zimmerman, T. S., McMillin, J. M., and Watson,
C. J., Archives of Internal Medicine, 1966, 118, McKenzie, A. W., and Acharya, U., British Fournal of Dermatology, 1972, 86, 453.

oldswain, P. R., and Eales, L., South African fournal of Laboratory and Clinical Medicine 1971, 17, 111 .

fournal of Clinical Pathology, 1972, 25, D. C.,

\section{Combination Chemotherapy for Breast} Cancer

SIR,-We recently (9 February 1974, p. 218) reported our initial experience in 25 cases with a combination chemotherapy regimen for metastatic breast cancer which included cyclophosphamide, methotrexate, and fluorouracil in addition to prednisone. At the present time we have achieved a complete or partial response in 26 out of 38 cases $(68 \%)$, which lasted for a median duration of eight months (range 6-34t). Eight of these patients achieved a complete disappearance of all measurable disease. The median survival for the responding group is 20 months and for the non-responding group five months. The haematological toxicity was greatest in those patients with hepatic functional impairment and extensive bone or bone marrow replacement by tumour. In these cases we recommend that the initial doses of cytotoxic drugs be reduced by $50 \%$, with modification of subsequent cycles according to haematological tolerance.-We are, etc.,

\section{G. P. CANELlos}

G. L. GOLD

B. A. Chabner

Medicine Branch,

National Cancer Institute, 